\title{
Açık Deniz Yapıları Kova Temel Sistemi Davranışı Üzerinde Tekrarlı Yük Frekansının Etkisi
}

\author{
H. Ercan TAȘAN ${ }^{1}$ \\ C. Taylan AKDAĞ $\breve{G}^{2}$
}

ÖZ

Açık deniz yapıları kova temel sistemi davranışının tahmini ile ilgili henüz yeterli bilgi birikimine ulaşılmamıştır. Açık deniz koşullarında temel sistemlerinin ağır tekrarlı yüklere maruz kalması nedeniyle zeminde kalıcı deplasman ve aşırı boşluk suyu basıncı gelişimi meydana gelir. Çalışmada çok ayaklı temel sitemi ile tasarlanmış açık deniz yapısının bir kova temelinin eksenel tekrarlı yükler altındaki davranışı sayısal analiz yöntemi ile incelenmiştir. Özellikle yük frekansının davranış üzerindeki etkisine odaklanılmıştır. Suya doygun zemin, hipoplastik malzeme modeli ve iki fazlı üç boyutlu sonlu elemanlar ile modellenmiştir. Analiz sonuçları, tekrarlı yük frekansının zeminde aşırı boşluk suyu basıncı gelişimi ve temelin deplasman birikimi üzerinde oldukça önemli etkileri olduğunu göstermiştir.

Anahtar Kelimeler: Açık deniz yapıları temeli, kova temel, sonlu elemanlar yöntemi, tekrarlı yük, hipoplastik zemin modeli, iki fazlı model, sayısal analiz, aşırı boşluk suyu basınc1, kalıcı deplasman.

\section{ABSTRACT \\ The Influence of Cylic Loading Frequency on the Behaviour of Suction-Bucket Foundations for Offshore Structures}

The behavior of suction-bucket foundation systems for offshore structures has not been adequately investigated yet. The foundations are subjected to large cyclic loading due to marine conditions which lead to accumulation of soil deformation and excess pore water pressure. A numerical investigation was conducted to study the response of one bucket support of a multipode foundation system under cyclic axial loading. Thereby a fully coupled two-phase model and a hypoplastic constitutive model were used for consideration of accumulation effects in a saturated soil medium. Special emphasis is attached to the influence of cyclic loading frequency on the behavior of the bucket-soil system. The results have

\footnotetext{
Not: Bu yaz1

- Yayın Kurulu'na 23.05.2016 günü ulaşmıştır. 25.07.2017 günü yayımlanmak üzere kabul edilmiştir.

- 31 Temmuz 2018 gününe kadar tartışmaya açıktır.

- DOI: $10.18400 /$ tekderg.337970
}

1 Orta Doğu Teknik Üniversitesi, İnşaat Mühendisliği Bölümü, Ankara - ercantasan@yahoo.de

2 Türk-Alman Üniversitesi, İnşaat Mühendisliği Bölümü, İstanbul - akdag@tau.edu.tr 
indicated that the frequency considerably affects the excess pore water pressure development and the vertical displacement accumulation of the bucket foundation.

Keywords: Offshore foundation, suction bucket, finite element method, cyclic loading, hypoplastic model, fully coupled two phase model, numerical analysis, excess pore water, permanent displacement.

\section{GİRIŞ}

Açık deniz yapıları için gerçekleştirilen alternatif temel sistemi arayışları sonucu kova temel sistemi kavramı geliştirilmiştir. Kova temel üst kısmı kapalı geniş çaplı boru tipi çelik silindirden oluşan açık deniz koşullarındaki ağır yüklere dayanıklı bir temel tipidir (Şekil 1). Kova temel tipi kurulum açısından yenilikçi bir yaklaşımı ifade etmektedir [1-3]. Temel, deniz tabanına konumlandırıldığında öncelikle kendi ölü ağırlığı nedeniyle bir miktar oturma gerçekleşmektedir. Bu esnada deniz tabanı ile temel üst plakası arasındaki boşluk deniz suyu ile dolu bulunmaktadır. Boşluktaki suyun deşarjı işlemi ile gelişen penetrasyon basıncı kimi durumlarda uygulanan ek ölü yükler (balast) kullanılarak temelin kurulumu gerçekleştirilir. Üst plaka tabanının deniz tabanına temasına kadar penetrasyona devam edilir.

Kurulumun sağlanması için temelin iç bölgesindeki suyun deşarjı sırasında oluşan penetrasyon basıncı ve üst yapı yükleri bileşiminin elbette temelin uç ve çevre sürtünmesinden oluşan direnç yüklerinden daha büyük olması gerekmektedir (Şekil 2). Penetrasyon basıncının oluşturulması esnasında oldukça dikkatli olunmalı ve kontrollü bir prosedür uygulanmalıdır. Temel içinde mevcut boşluktaki suyun deşarj edilmesi esnasında zemin içindeki suyun da çekilmesi sözkonusu olmaktadır. Temelin dış çevresindeki suyun temelin içine doğru akışı kum zeminlerde genellikle yüksek hidrolik eğim ile gerçekleşir ve özellikle homojen kum zeminde borulanma olarak isimlendirdiğimiz olgunun meydana gelmesine neden olabilir [4]. Kritik deşarj basıncında temel ucundaki zeminin efektif gerilme değeri borulanma nedeniyle sıfır değerine ulaşarak zeminin yenilmesine neden olmaktadır ve bu nedenle temel kurulumu başarısızlıkla sonuçlanabilmektedir [5-7].

Açık deniz ortamında kazıklı temel sistemi uygulamasında, kazığın çakılması esnasında oluşan etkiler deniz canlılarının korunumu açısından önemli bir meseledir. Örneğin, Almanya'da kazık çakılması esnasında meydana gelen gürültünün emisyonu konusunda deniz yaşamını korumadan sorumlu onay makamları önemli sınırlamalar getirmiştir. $\mathrm{Bu}$ anlamda, kova temel tipi açık deniz yapıları için önemli avantajlar sunmaktadır. Kova temel sisteminin kurulumu esnasında meydana gelen gürültü, kazıkların çakılmasından dolayı oluşan gürültüye göre oldukça düşüktür ve öngörülen sınırlar içerisinde kalmaktadır. Böylelikle gürültünün azaltılmasına yönelik maaliyeti yüksek ek sistemlere ihtiyaç bulunmamaktadır. $\mathrm{Bu}$ nedenle kova temel sistemleri özellikle Almanya'nın Kuzey Denizi'nde kumlu zemin içerisinde önümüzdeki yıllarda kurulacak onlarca açık deniz rüzgar enerjisi çiftlikleri için tercih edilebilir bir alternatif temel tipi olarak sorumlu onay makamlarına tanıtılmıştır.

Kova temeller çevre dostu kurulum özelliği taşımasının yanı sıra kurulumu için gerekli zaman ve giderlerin görece düşük olması açısından da avantajlar sağlamaktadır. Ayrıca kullanım sonrası daha hızlı ve kolay sökülebilme özellikleri nedeniyle de açık deniz yapıları için tercih edilebilir bir alternatif temel potansiyeli taşımaktadır. 
Kova temel sistemleri tekil kazık ve ağırlık temel sistemlerinin kimi önemli özelliklerini birarada bulunduran hibrid bir tasarım olduğundan açık deniz rüzgar enerjisi, açık deniz platformları ve açık deniz ölçüm direkleri gibi yapıların temel sistemi olarak kullanilabilmektedir [8-10].

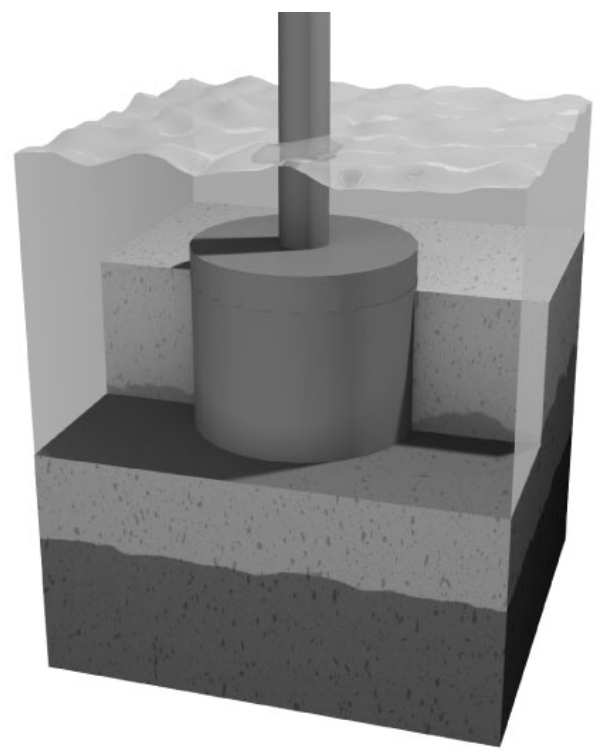

Şekil 1. Açık deniz yapıları için uygulanan kova tipi temel

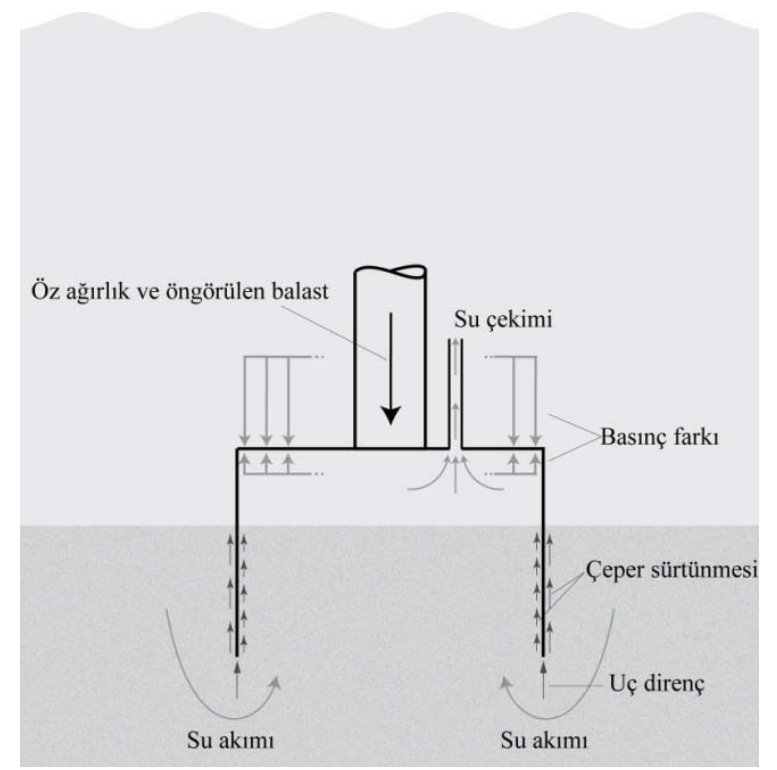

Şekil 2. Kova temel sistemi kurulumu esnasında etki eden kuvvetler 
Kova temel sistemleri tek ayaklı (monopod) ve çok ayaklı temel sistemi (multipod) olmak üzere iki tipte tasarlanmaktadır (Şekil 3). Her iki tip için üst yapıdan temele aktarılan yükler farklılık içerir. Rüzgar, dalga ve akıntıdan oluşan yatay tekrarlı yük üst yapıya etki ederek bir moment yükü oluşturur. Böylelikle tek ayaklı kova temel sistemi eksenel ölü yükün yanı sıra tekrarlı yatay ve moment yüküne maruz kalır. Çok ayaklı temel sistemde yatay tekrarlı yük neticesinde olusan momentler her bir kova temele eksenel tekrarlı yük olarak transfer edilir. Tekrarlı eksenel yük yatay yükün yönüne göre tekrarlı temele eksenel basınç veya çekme yükü olarak etki eder. Bu çalışmada ele alınmayan eksenel çekme yükleri, açık deniz rüzgar enerjisi türbinleri gibi düşük ağırlığa sahip yapılarda kritik bir durum oluşturmaktadır [11].
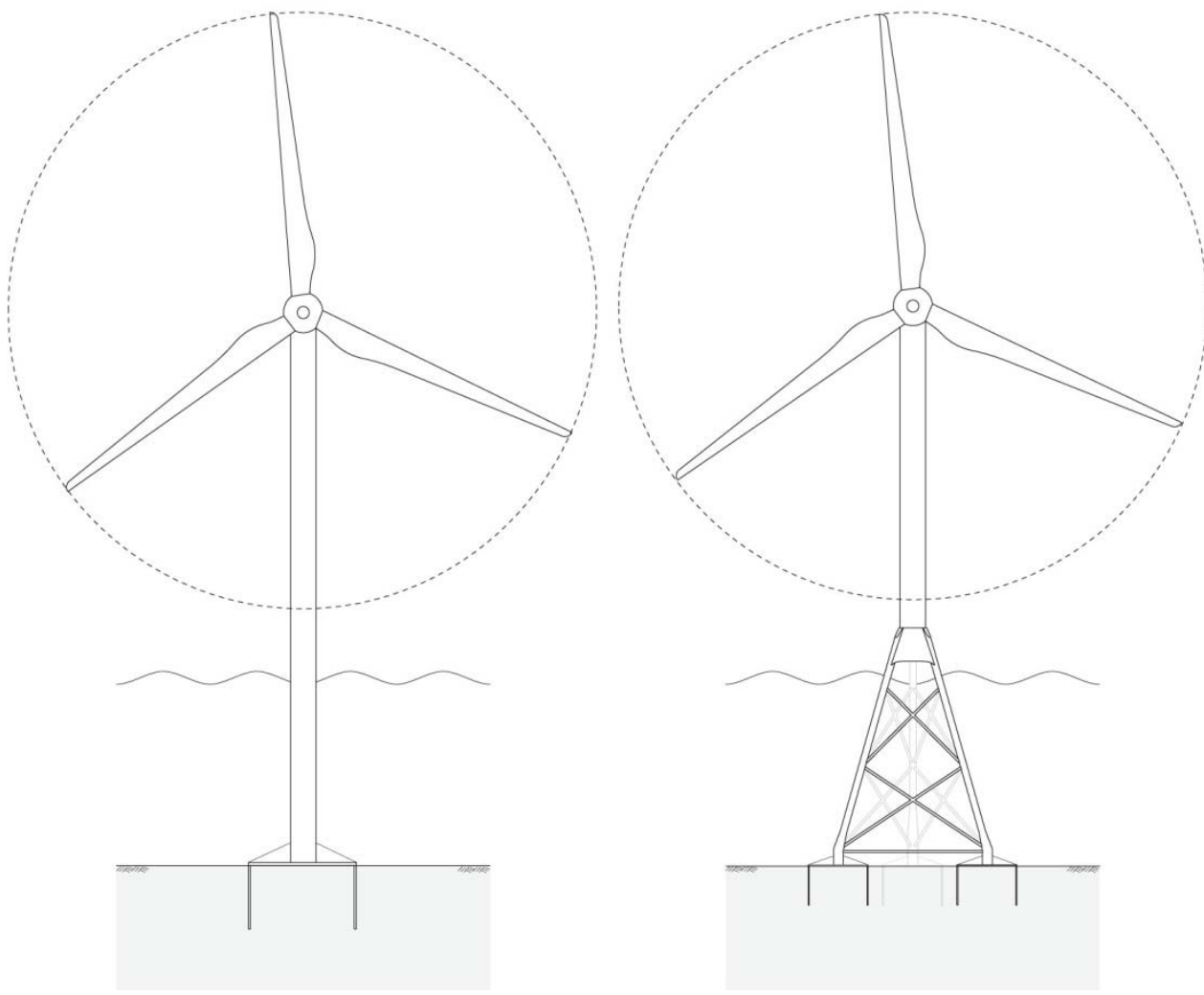

Şekil 3. Kova temel sistemi tasarımı: a-Tek ayaklı kova temel (Monopod) b-Çok ayaklı kova temel (Multipod)

Kova temel sisteminin boyutlandırılmasında rüzgar, dalga ve akıntıdan kaynaklanan tekrarlı yükün etkisi önemli rol oynamaktadır. Söz konusu yük etkisi nedeniyle temelin tabanında ve çevresindeki zeminde kalıcı deformasyon birikimi, kova temelde kalıcı deplasman veya dönme gerçekleşebilmektedir [12-14]. Vurgulamak gerekir ki kova temel-zemin sisteminin davranışında aşırı boşluk suyu basıncı gelişimi önemli bir etkiye sahiptir $[15,16]$. 
Suya doygun zemin koşullarında tekrarlı yükleme altında temel-zemin sisteminde meydana gelen deplasman gelişimi yük büyüklüğü, yük frekansı ve drenaj koşullarına doğrudan bağlıdır ve davranış oldukça komplikedir. Açık deniz ortamında suya doygun zemindeki suyun göreceli olarak sıkışamaz nitelikte olması nedeniyle yükleme ve drenaj koşullarına bağlı olarak zeminde aşırı boşluk suyu basıncı oluşumu gerçekleşebilir. Zemin hidrolik iletkenliğinin ve yükleme periyodunun düşük olduğu, ek olarak suyun drenaj yolunun uzun olduğu koşullarda zemine iletilen gerilmenin sönümlenmesi, suyun drene olması ve boşluk hacminin küçülmesi ani veya hızlı olarak gerçekleşemediğinden öncelikle zeminde tepki olarak aşırı boşluk suyu basıncı birikimi meydana gelir $[17,18]$.

Açık deniz yapıları temelleri için uygun olan kova temel sisteminin davranışına ilişskin önemli ölçüde bilgi ve deneyim eksikliği bulunmaktadır. Söz konusu yapıların kullanım ömrü boyunca stabilitesinin sağlanabilmesi amacıyla bu alanda kapsamlı araştırmalara ihtiyaç bulunmaktadır. Bu anlamda katkı sunacağı düşünülen mevcut çalışmada kova temelzemin temel sisteminin tekrarlı eksenel yük altındaki davranışı sayısal analiz yöntemi ile incelenmiştir. Analizlerde özellikle tekrarlı yük frekansının aşırı boşluk suyu basıncı gelişimi ve temel deplasman birikimi üzerindeki etkisine odaklanılmıştır.

\section{YÖNTEM}

Araştırma sayısal analiz yöntemine dayanmaktadır. Sonlu elemanlar analizlerinde suya doygun zeminde tekrarlı yükleme altında oluşabilecek boşluk suyu basınç birikimlerinin elde edilmesi amacıyla geliştirilen üç boyutlu sonlu elemanlar, hipoplastik malzeme modeli ile birlikte kullanılmıştır.

Kova temel-zemin sisteminin sayısal analizi için çok farklı fiziksel problemlerin simulasyonuna uygun eleman zenginliğine sahip ANSYS sonlu elemanlar programı kullanılmıştır. Program kullanıcıya arayüz aracılı̆̆ıyla eleman kütüphanesine probleme uygun eleman ekleme ve ek malzeme modelini uygulama olanağı tanımaktadır [19]. Bu çalışma kapsamında iki fazlı model temel alınarak üç boyutlu sonlu eleman geliştirilmiş ve hipoplastik malzeme modeliyle birlikte ANSYS programına eklenmiştir.

\subsection{Malzeme Modeli}

Zemin gerilme seviyesinin ve birim hacim ağırlığı değiş̧iminin zemin davranışı üzerindeki etkisinin özellikle dikkate alındığı hipoplastik malzeme modeli kohezyonsuz zeminlerin tekrarlı yük altındaki davranışının modellenmesi için oldukça uygun bir malzeme modelidir [20, 21]. Rijitlik, genleşme, büzülme, pik sürtünme açısı, zemin gerilme durumu ve deformasyon yönü modelde dikkate alınan temel parametre ve kavramlardır.

Hipoplastik model aşamalı doğrusal olmayan gerilme deformasyon ilişkisine bağlı malzeme modeli yaklaşımına dayanmaktadır. Hipoplastik modeli genel anlamda aşağıda sunulan fonksiyon (1) ile ifade edebiliriz.

$$
\dot{\sigma}=f(\sigma, \dot{\varepsilon})
$$


Denklemde $\sigma$ Jaumann objektif gerilme oranını, $\boldsymbol{\sigma}$ mevcut gerilme durumunu ve $\dot{\boldsymbol{\varepsilon}}$ birim deformasyon oranını ifade etmektedir. Oran ifadesini sonsuz derecede küçük bir zaman aralığındaki artış olarak tanımlayabiliriz.

Hipoplastik malzeme modeli üzerine gerçekleştirilen birçok çalışma mevcuttur. [21-25]. Bu araştırmada Wolffersdorff'un [25] çalışmasına dayanan hipoplastik malzeme modeli kullanılmıştır. Modelde plastik ve elastik deformasyonların tanımlanması amacıyla tek bir tensörel denklem oluşturulmuştur (2) [21, 26].

$$
\stackrel{\sigma}{\sigma}=\mathbf{L}: \dot{\varepsilon}+\mathbf{N}\|\dot{\varepsilon}\|
$$

Denklemde dördüncü dereceden tensör $\mathbf{L}$ hipoplastik rijitlik tensörünün doğrusal, ikinci dereceden $\mathbf{N}$ tensörü ise doğrusal olmayan kısmını ifade etmektedir. Wolffersdorff'un çalışmasına dayanan hipopilastik modelinin $\mathbf{L}$ ve $\mathbf{N}$ tensörleri denklem (3) den denklem (12) ye kadar ayrıntılı bir şekilde tanımlandığı üzere Matsuoka-Nakai göçme kriteri kullanılarak elde edilmektedir.

$$
\begin{aligned}
& \mathbf{L}=\frac{f_{s} a^{2}}{\widehat{\boldsymbol{\sigma}}: \hat{\boldsymbol{\sigma}}}\left(\left(\frac{F}{a}\right)^{2} \mathbf{I}+\widehat{\boldsymbol{\sigma}} \otimes \widehat{\boldsymbol{\sigma}}\right) \\
& \mathbf{N}=\frac{f_{s} f_{d} a}{\widehat{\boldsymbol{\sigma}}: \widehat{\boldsymbol{\sigma}}}\left(\widehat{\boldsymbol{\sigma}}+\widehat{\boldsymbol{\sigma}}_{d}\right)
\end{aligned}
$$

I ve $\widehat{\boldsymbol{\sigma}}$ tensörleri denklem (5) ve denklem (6) da ifade edilmiştir.

$$
\begin{aligned}
& I_{i j k l}=\frac{1}{2}\left(\delta_{i k} \delta_{j l}+\delta_{i l} \delta_{j k}\right) \\
& \widehat{\boldsymbol{\sigma}}=\frac{\boldsymbol{\sigma}}{t r \boldsymbol{\sigma}} ; \widehat{\boldsymbol{\sigma}}_{d}=\widehat{\boldsymbol{\sigma}}-\frac{\widehat{\boldsymbol{\sigma}}: \boldsymbol{\delta}}{3} \boldsymbol{\delta}
\end{aligned}
$$

Skaler gerilme fonksiyonu $F$ ve $a$ Matsuoka-Nakai göçme yüzeyini tanımlayan parametreler ile denklem (7) ve denklem (9) de ifade edilmiştir:

$$
\begin{aligned}
& F=\sqrt{\frac{3 \widehat{\boldsymbol{\sigma}}_{d}^{2}}{8}+\frac{2-\widehat{\boldsymbol{\sigma}}_{d}{ }^{2}}{2+\sqrt{2}\left\|\widehat{\boldsymbol{\sigma}}_{d}\right\| \cos 3 \theta}}-\frac{\left\|\widehat{\boldsymbol{\sigma}}_{d}\right\|}{2 \sqrt{2}} \\
& \cos 3 \theta=\frac{-\sqrt{6} \operatorname{tr}\left(\widehat{\boldsymbol{\sigma}}_{d} \cdot \hat{\boldsymbol{\sigma}}_{d} \cdot \widehat{\boldsymbol{\sigma}}_{d}\right)}{\left(\widehat{\boldsymbol{\sigma}}_{d}::_{d}\right)^{\frac{3}{2}}} \\
& a=\frac{\sqrt{3}\left(3-\sin \varphi_{c}\right)}{2 \sqrt{2} \sin \varphi_{c}}
\end{aligned}
$$

Denkelmde $\varphi_{\mathrm{c}}$ parametresi daneli zeminlerin en gevşek durumu için kritik içsel sürtünme açısını ifade etmektedir. İlkköşegen toplamı olan $t r$, matrisin diagonal elemanlarının toplamıdır, $\delta$ ise ikinci dereceden tensör. Birim hacim ağırlık ve basınç etkilerini dikkate 
almak için $f_{s}$ ve $f_{d}$ parametreleri $\mathbf{L}$ ve $\mathbf{N}$ tensörlerine eklenmiştir. Denklem (10) da gösterildiği üzere $f_{s}$ basınç değişiminin davranış üzerindeki etkisini ve boşluk oranı değişiminin rijitlik üzerindeki etkisini dikkate almaktadır.

$f_{S}=\frac{\frac{h_{S}}{n}\left(\frac{1+e_{i}}{e_{i}}\right)\left(\frac{e_{i}}{e}\right)^{\beta}\left(\frac{-t r \sigma}{h_{S}}\right)^{1-n}}{3+a^{2}-\sqrt{3} a\left(\frac{e_{i 0}-e_{d 0}}{e_{c 0}-e_{d 0}}\right)^{a}}$

Birim hacim ağırlık değişiminin etkisi $f_{d}$ büyüklüğü ile kontrol edilmektedir.

$f_{d}=\left(\frac{e-e_{d}}{e_{c}-e_{d}}\right)^{a}$

$\frac{e_{i}}{e_{i 0}}=\frac{e_{c}}{e_{c 0}}=\frac{e_{d}}{e_{d 0}}=\exp \left(-\left(\frac{3 p}{h_{s}}\right)^{n}\right)$

Kullanılan parametreler arasında boyutlu tek değişken olan $h_{\mathrm{s}}$, danelerin sıkışabilirliğini ifade eden bir rijitlik parametresidir. Danenin sertliğine, şekline ve dane çapı dağılımına bağlı bir parametredir. Oransal sıkışma ifadesinde üstel bir parametre olan $n, h_{\text {s }}$ parametresi ile doğrudan ilişkili olup dane büyüklüğü ve dane çapı dağılımına bağlıdır. Gerilmeye bağlı üç sınır boşluk oranı tanımlanmıştır: $e_{d 0}$, minimum boşluk oranını $e_{c 0}$, kritik boşluk oranını ve $e_{i 0}$ maksimum boşluk oranını ifade etmektedir. Üstel bir parametre olan $\alpha$ daneli zeminlerdeki sıkılığın pik sürtünme açısı üzerindeki etkisini tanımlayan bir parametredir. Bir diğer üstel parametre olan $\beta$ sabit birim deformasyon ve sabit ortalama basınç durumunda sıkılığın artışıyla birlikte artan gerilme oranını ifade eden bir parametredir.

Modelde kullanılan kumun hipoplastik zemin parametreleri Tablo 1'de sunulmuştur. Hipoplastik malzeme modeli toplamda sekiz parametre ile tanımlanır [25, 27, 28].

Tekrarlı yüklerin zemin davranışı üzerindeki etkisini inceleyebilmek amacıyla Wolffersdorff'un [25] çalışmasındaki hipoplastik malzeme modeli Niemunis ve Herle [24] tarafından eklenen beş parametre ile genişletilmiştir. Eklenen parametrelerden $R$, danelerarası birim deformasyonu, $m_{\mathrm{R}}$ ve $m_{\mathrm{T}}$ rijitlik faktörlerini ifade etmektedir. $\beta_{\mathrm{r}}$, danelerarası birim deformasyon gelişiminin etkisini ifade etmektedir. $\chi$, rijitliğin azalmasını ifade eden üstel bir parametredir.

Tablo 1. Nümerik modelde kullanılan kumun özellikleri

\begin{tabular}{c|c|c|c|c|c|c|c}
$\varphi_{\mathrm{c}}\left(^{\circ}\right)$ & $h_{\mathrm{s}}(\mathrm{MPa})$ & $n$ & $e_{d 0}$ & $e_{c 0}$ & $e_{\mathrm{i} 0}$ & $\alpha$ & $\beta$ \\
\hline 32.0 & 3730 & 0.20 & 0.41 & 0.74 & 0.89 & 0.14 & 1.0 \\
& $R$ & $m_{R}$ & $m_{T}$ & \multicolumn{2}{|c}{$\beta_{r}$} & \multicolumn{2}{|c}{$\chi$} \\
\hline & $1 \cdot 10^{-4}$ & 5.0 & 2.0 & 0.4 & \multicolumn{2}{|c}{6.0}
\end{tabular}




\section{2. İki Fazlı Model}

$\mathrm{Bu}$ çalışmada üç boyutlu sonlu elemanlar analizlerinde zeminde aşırı boşluk suyu basıncı gelişiminin belirlenmesi amacıyla iki fazlı model kullanılmıştır. İki fazlı model kullanımı ile suya doygun zemin sonlu elemanlar modelinde tanımlanabilmiş ve böylelikle analizlerde aşırı boşluk suyu basıncı gelişiminin elde edilmesi mümkün olabilmiştir.

Boşluk suyunun malzeme davranışı üzerinde etkili olduğu geoteknik problemlerin tanımlanmasında iki fazlı model oldukça elverişli bir modeldir. İki fazlı modelde katı faz zemin danelerini ifade ederken sıvı faz ise boşluk suyunu ifade etmektedir (Şekil 4a). Bu çalışma kapsamında u20p8 olarak isimlendirilen iki fazlı modele dayanan üç boyutlu elemanlar geliştirilmiştir (Şekil 4b). Deplasman tahmini 20 düğüm noktasından oluşan (u20) trikuadratik enterpolasyon fonksiyonlarıyla ve boşluk suyu basıncı tahmini ise 8 köşe düğüm noktasından oluşan (p8) trilineer enterpolasyon fonksiyonlarıyla gerçekleştirilmiştir.
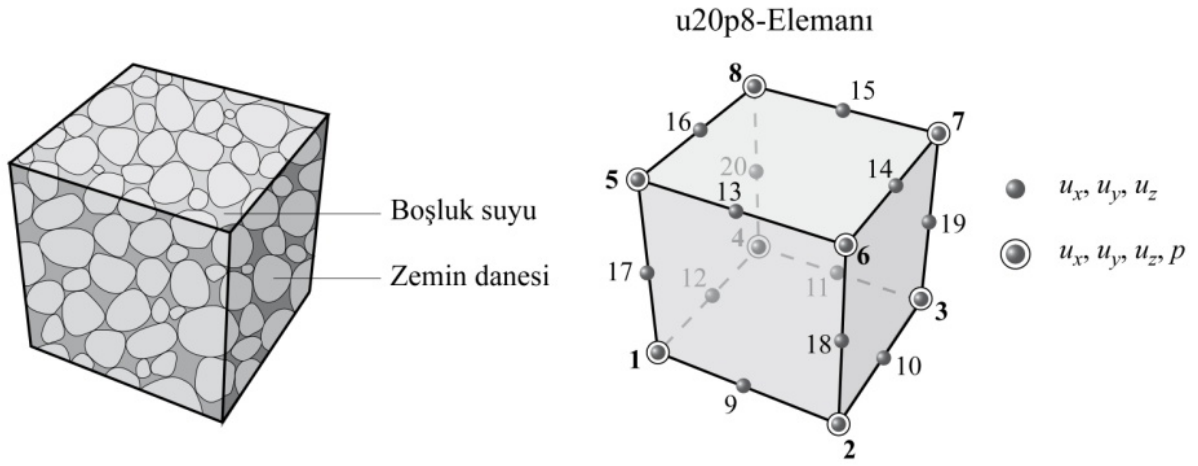

Şekil 4. Zemin elemanı (a) iki fazlı model (b) üç boyutlu iki fazlı sonlu eleman modeli

Suyun sıkışabilirliğinin ve zemin hidrolik iletkenliğinin oldukça küçük olduğu durumda tekrarlı yükleme altında oluşan aşırı boşluk suyu basıncında meydana gelen salınım nedeniyle geliştirilen sonlu elemanlarda nümerik instabilite problemi ile karşılaşılır [29-32]. Sözkonusu etki aynı derecede kullanılan şekil değiştirme ve boşluk suyu basıncı yaklaşım fonksiyonlarında daha açık bir şekilde belirir. Yüksek dereceli bir şekil değiştirme yaklaşım fonksiyonunun seçilmesi ile gerekli olan stabil eleman davranışı sağlanır [32-34].

İki fazlı modelin oluşturulmasında kullanılan temel denklemler [16, 35] referanslarında ayrıntılı olarak açıklanmıştır. İki fazlı sonlu elemanların doğrulamasını gerçekleştirmek amacıyla bir kil tabakasının konsolidasyonu [36] ve Hochstetten kumunun tekrarlı yükler altındaki davranışının drenajsız koşullarda incelendiği [24] iki araştırma ele alınmıştır [35]. Söz konusu araştırmalardaki zeminler u20p8 iki fazlı elemanlar ile ve hipoplastik malzeme modeli kullanılarak modellenerek doğrulama gerçekleştirilmiştir [35]. 


\section{AÇIK DENİZ KOVA TEMEL-ZEMIN SİSTEMI SONLU ELEMANLAR MODELI}

Çalışmanın temel amacı özellikle tekrarlı yük frekansına bağlı olarak suya doygun zeminde gelişen boşluk suyu basıncı birikiminin temel-zemin davranışı üzerindeki etkisinin belirlenmesidir. Bu amaçla çalışmada özellikle yük frekansının davranış üzerindeki etkisi üç boyutlu sonlu elemanlar yöntemi ile incelenmiştir.

Her ne kadar yük karakteristiği ve geometrik açıdan temel-zemin sistemi eksenel simetrik özelliğe sahip olsa da ilerideki çalışmalarda temel sistenminin yatay ve moment yüklerinden oluşan kombine yükler altındaki davranışının incelenmesi planlandığından sistem üç boyutlu sonlu elemanlar modeli ile modellenmiştir.

Temel, batma derinliği $l$, et kalınlığı $t_{0}$ ve dış çapı $d$ olmak üzere üstü kapalı yarım silindir olarak modellenmiştir. Zemin sonlu elemanlar ağı u20p8 iki fazlı elemanlar ile ve temel sonlu elemanlar ağı ise 20 düğüm noktasından oluşan sürekli trikuadratik elemanlar ile oluşturulmuştur.

Şekil 5 de kova çapı, $d$ ye bağlı olarak sunulan model boyutları yükleme esnasında model sınırlarında herhangi bir etkinin oluşmayacağı yeterli genişlikte tasarlanmıştır. Zemin, kazığın çevresinde $3.5 d$ genişliğinde dairesel olarak ve temel tabanı altında $4.0 \mathrm{~d}$ derinliğinde modellenmiştir. Sınır koşulları tanımlanırken model tabanı $x, y, z$ yönlerinde deplasmanlara kısıtlanmıştır. Benzer bir şekilde model simetri yüzeyi yüzeye dik $y$ ve model çevresi $x, y$ yönlerinde deplasmanlara kısıtlanmıştır.

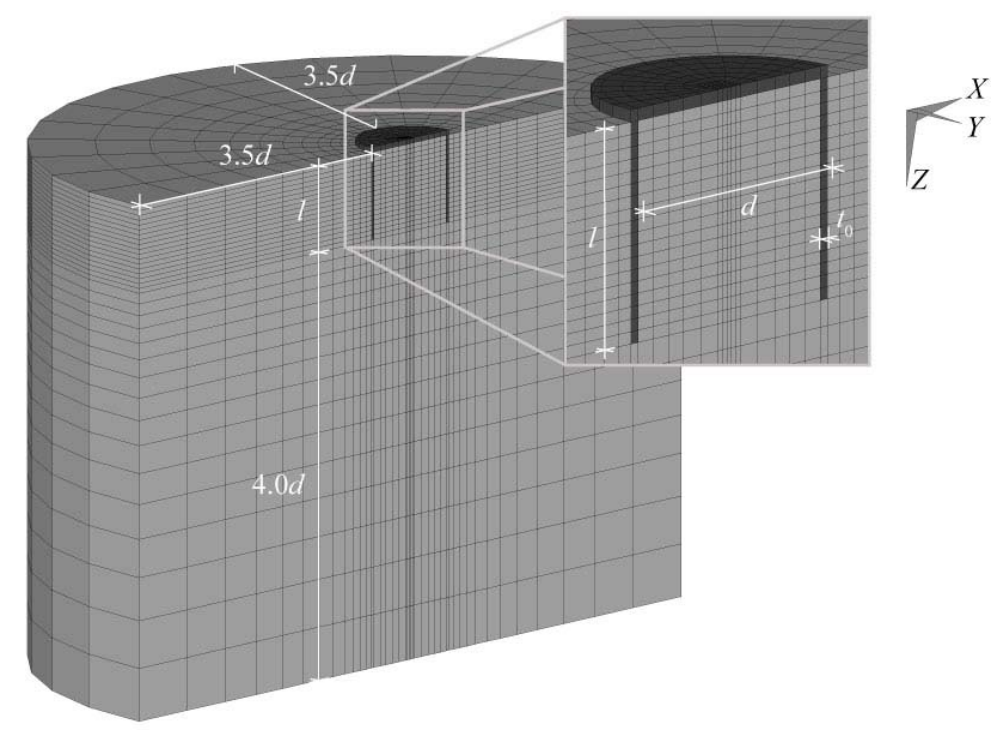

Şekil 5. Kova temel-zemin sonlu elemanlar modeli

Zemin yüzeyi geçirimli olarak modellenmiştir. Kesitteki temel-zemin sınır yüzeyleri de dahil olmak üzere diğer sınır yüzeyleri geçirimsiz olarak modellenmiştir. Model toplam gerilme ve boşluk suyu basıncı tanımlanarak kurulmuştur. Böylelikle model yüzeyindeki hidrostatik 
basınç ve boşluk suyu basıncı ortalama su derinliği $h$ dikkate alınarak modelde tanımlanmıştır. (Tablo 2).

Temel, çelik malzeme özellikleri dikkate alınarak elastisite modülü $E=2.1 \cdot 10^{8} \mathrm{kN} / \mathrm{m}^{2}$ ve Poisson oranı $v=0.3$ malzeme özelliklerinde modellenmiştir. Temel-zemin yüzeyi "surfaceto-surface" kontak elemanları ile tanımlanarak sürtünme açısı $\delta=21^{\circ}$ olarak uygulanmıştır. Temel üst plakası rijit olarak modellenmiştir.

Deneyler sonucu kuru kumun minimum ve maksimum kuru birim hacim ağırlıkları sırasıyla: $\gamma_{\mathrm{d}, \min }=1.52 \mathrm{~g} / \mathrm{cm}^{3}, \gamma_{\mathrm{d}, \max }=1.88 \mathrm{~g} / \mathrm{cm}^{3}$, dane birim hacim ağırlı̆̆ $1: \gamma_{\mathrm{s}}=2.66 \mathrm{~g} / \mathrm{cm}^{3}$ ve hidrolik iletkenliği: $k_{\mathrm{d}}=2 \cdot 10^{-4} \mathrm{~m} / \mathrm{s}$ olarak elde edilmiştir. Analizlerde kullanılan efektif birim hacim ağırlığ $\gamma$, zemin relatif sıkılık $I_{\mathrm{D}}$ ve permeabilite $k_{\mathrm{d}}$ değerleri Tablo 2 de sunulmuştur. Çalışma, Kuzey Denizi tabanındaki zemin koşullarına benzer olarak sıkı homojen kum zemin koşullarında gerçekleştirilmiştir.

Çalışmada, Almanya’nın Kuzey Denizi sınırlarında dört ayaklı kova temel sistemi ile tasarlanmış bir açık deniz platform yapısı dikkate alınmıştır. Analizler platformun bir kova temel sistemi için gerçekleştirilmiştir. Sistemde kova temele etki eden yapısal eksenel statik ölü yük $V_{\text {stat }}$ Tablo 2 de sunulduğu üzere $22 \mathrm{MN}$ değerindedir. Bunun yanı sıra rüzgar, dalga ve akıntıdan kaynaklanan ve temele eksenel olarak transfer edilen tekrarlı yük $\tilde{V}=5 \mathrm{MN}$ Şekil 6 da görüldüğü şekilde idealize edilmiştir. Böylelikle söz konusu eksenel tekrarlı yükün zeminde oluşturduğu aşırı boşluk suyu basıncı gelişimi elde edilmiştir. Tekrarlı yükleme Kuzey Denizi'nde meydana gelebilecek dalga yükü frekansları dikkate alınarak üç farklı frekansta gerçekleştirilmiştir [37].

Sonlu elemanlar analizleri birçok aşamada gerçekleştirilmiştir. Başlangıç aşamasında suya doygun zeminin kendi ağırlığından kaynaklanan geostatik gerilme durumu oluşturulmuştur. Sonraki aşamada sürekli elemanlardan oluşan kova temel geometrisi ilgili zemin elemanları (u20p8-Elemente) ile yer değiştirilerek temelin ölü ağırlığı dolayısıyla meydana gelen gerilmeler elde edilmiştir. Takip eden aşamada temele etki eden statik üstyapı ağırlığı $V_{\text {stat }}$ uygulanmıştır. Statik yükleme nedeniyle zeminde meydana gelen boşluk suyu basıncının sönümlenmesinin ardından son aşama olarak tekrarlı eksenel yük Şekil 6 da sunulduğu şekilde uygulanmıştır.

Tablo 2. Sonlu elemanlar analizlerinde kullanılan tasarım parametreleri

\begin{tabular}{|c|c|c|c|c|c|c|}
\hline \multicolumn{3}{|c|}{ Kova temel } & \multicolumn{3}{c|}{ Kum } & Su derinliği \\
\hline $\begin{array}{c}\mathrm{d} \\
{[\mathrm{m}]}\end{array}$ & $\begin{array}{c}1 \\
{[\mathrm{~m}]}\end{array}$ & $\begin{array}{c}\mathrm{t}_{0} \\
{[\mathrm{~m}]}\end{array}$ & $\begin{array}{c}\gamma \\
{\left[\mathrm{kN} / \mathrm{m}^{3}\right]}\end{array}$ & $I_{\mathrm{D}}$ & $\begin{array}{c}k_{\mathrm{d}} \\
{[\mathrm{m} / \mathrm{s}]}\end{array}$ & $\begin{array}{c}\mathrm{h} \\
{[\mathrm{m}]}\end{array}$ \\
\hline 12.0 & 10.0 & 0.06 & 11.5 & 0.92 & $2 \cdot 10^{-4}$ & 39.5 \\
\hline
\end{tabular}

\begin{tabular}{|c|c|c|}
\hline \multicolumn{3}{|c|}{ Yük } \\
\hline $\begin{array}{c}V_{\text {stat }} \\
{[\mathrm{MN}]}\end{array}$ & $\begin{array}{c}\tilde{\mathrm{V}} \\
{[\mathrm{MN}]}\end{array}$ & $\begin{array}{c}\mathrm{f} \\
{[\mathrm{Hz}]}\end{array}$ \\
\hline 22 & 5 & $0.06,0.12,0.24$ \\
\hline
\end{tabular}




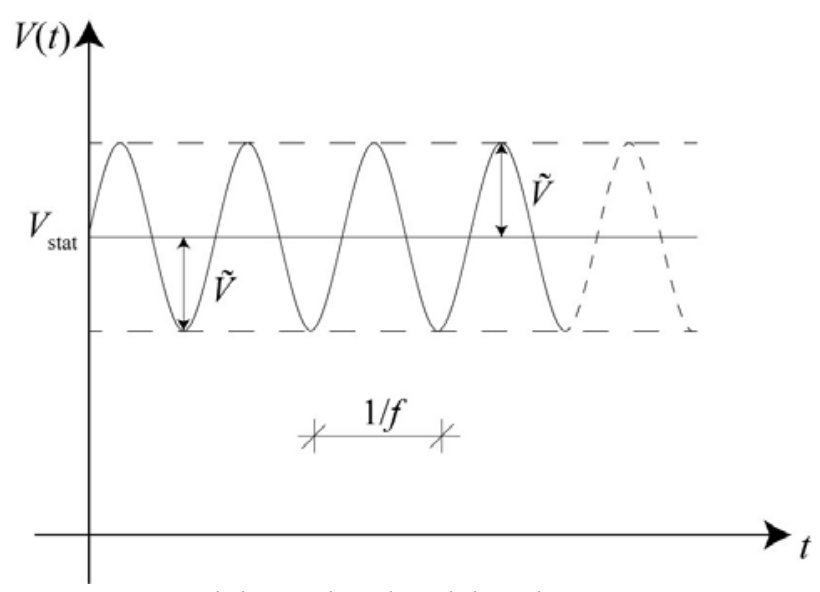

Şekil 6. Tekrarl yük karakteristiği

\section{SAYISAL ANALIZ SONUÇLARI}

Tekrarlı eksenel yükleme analizleri sonucu $f=0.06 \mathrm{~Hz}$ ve $f=0.24 \mathrm{~Hz}$ frekans durumlarında, $N=1.25, N=6.25$ ve $N=11.25$ yük tekrar sayıları anında meydana gelen aşırı boşluk suyu basınc1 $(\Delta p)$ gelişimi Şekil 7-9 da sunulmuştur.

Temel sistemi, uygulanan eksenel yükü temel iç ve diş yüzeyine sürtünme kuvvetleri, temel tabanına uç direnci ve temel üst plakası altındaki zemine basınç gerilmeleri olarak aktarır. Ele alınan örnekte olduğu gibi zemin permeabilitesi ve drenaj koşullarına bağlı olarak suya doygun zeminde tekrarlı yükleme sonucu aşırı boşluk suyu basıncı gelişimi meydana gelir. Yukarıda ifade edildiği üzere Kuzey Denizi'ndeki tekrarlı yük koşulları dikkate alınarak görece yavaş $(f=0.06 \mathrm{~Hz})$ ve ilkine göre dört kat daha hızlı $(f=0.24 \mathrm{~Hz})$ iki yükleme koşullarında gerçekleştirilen analizler sonucu zeminde oluşan aşırı boşluk suyu basıncı gelişimi belirlenmiş̧ir. Belirli yük tekrarlarında elde edilen ve Şekil 7-9 da sunulmuş analiz sonuçları göstermektedir ki her iki yükleme frekansında da özellikle temel içindeki zeminde dikkate değer aşırı boşluk suyu basıncı gelişimi meydana gelmiş̧ir. Dikkat çekmek isteriz ki en yüksek değerde aşırı boşluk suyu basıncı gelişimi başlangıç yük tekrarlarında meydana gelmiştir (Şekil 7).

Analiz sonuçları göstermektedir ki aşırı boşluk suyu basıncı gelişimi temel derinliği boyunca meydana gelmiştir. Bu sonuç, tekrarlı yükleme sonucu sadece sürtünme yüzeyinin değil aynı zamanda uç direncinin de aşırı boşluk suyu basıncı gelişiminden etkilendiğini ifade etmektedir.

Hızlı yükleme veya yüksek frekans durumunda $(f=0.24 \mathrm{~Hz})$ sadece başlangıç yük tekrarı değil aynı zamanda ilerleyen yük tekrarlarında da yüksek değerde aşırı boşluk suyu basıncı gelişimi gözlemlenmiştir. Ayrıca, yüksek frekansta ve ilerleyen yük tekrarlarında yüksek aşırı boşluk suyu basıncı gelişimi temel içinde derinlik boyunca yayılımını korumuştur. Yavaş yükleme durumunda $(f=0.06 \mathrm{~Hz})$ ise başlangıçta yüksek aşırı boşluk suyu basıncı temel içinde derinlik boyunca dağılım gösterirken devam eden yük tekrar sayılarında aşırı boşluk basınç değeri azalmıştır. Ek olarak aşırı boşluk suyu basıncı dağılımı ilerleyen tekrar sayılarında lokalize olma özelliğini yitirip temel üst plaka tabanı boyunca yayılma eğilimi göstermiş̧ir (Şekil 8-9). 
Açık Deniz Yapıları Kova Temel Sistemi Davranışı Üzerinde Tekrarlı Yük ...

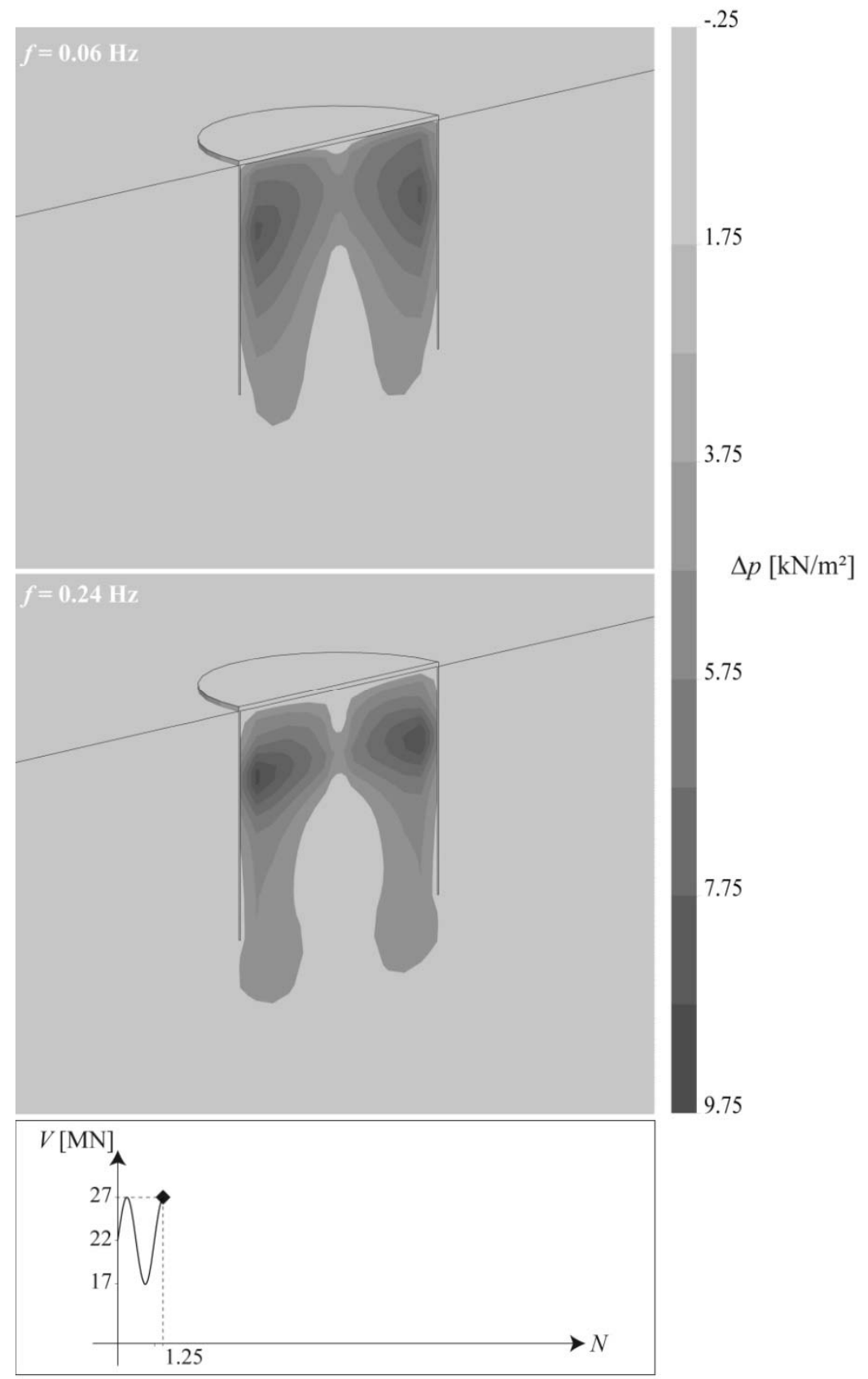

Şekil 7. Aşırı boşluk suyu basıncı gelişimi $\Delta p$ : tekrarlı yük sayısı $N=1.25$ 


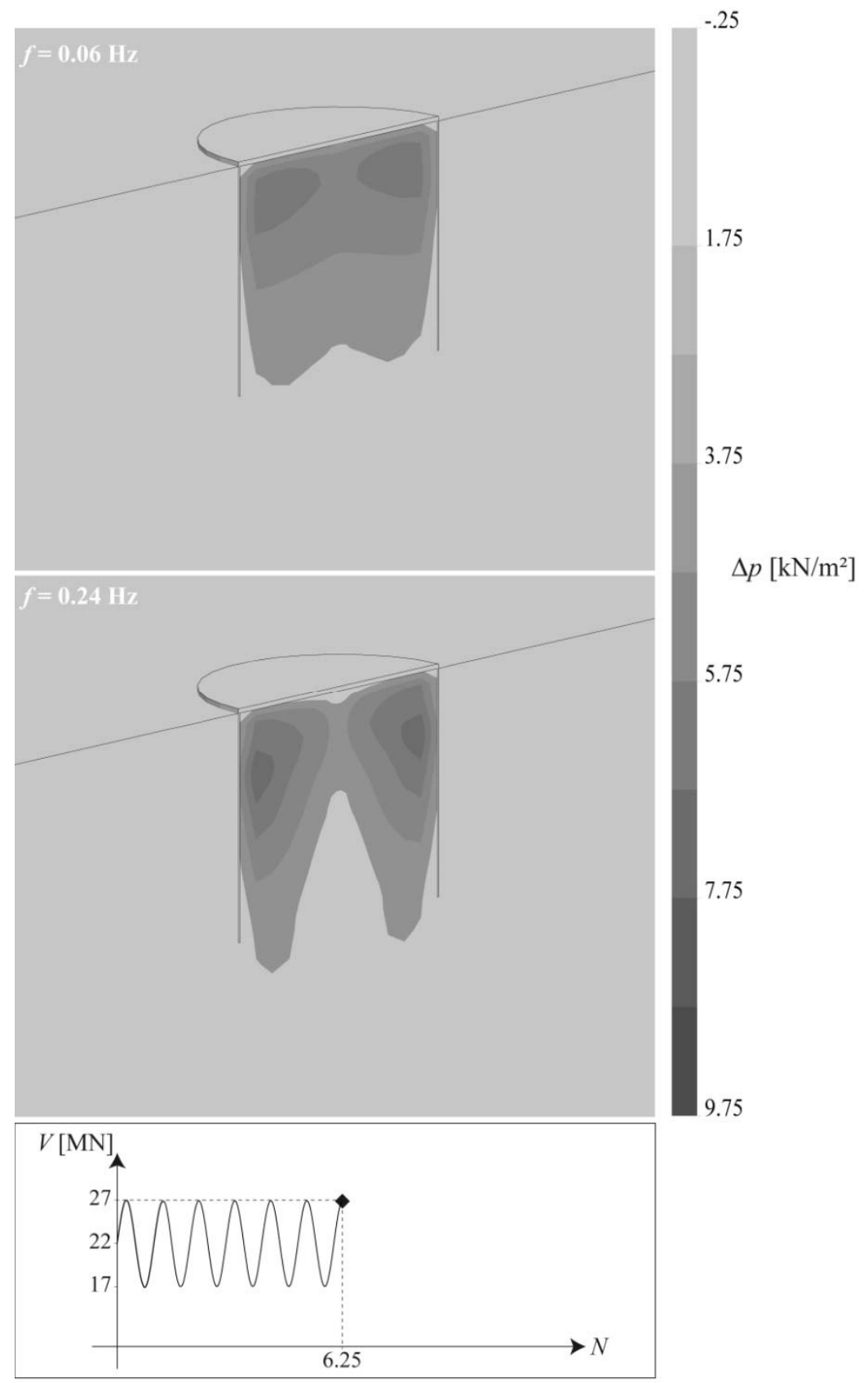

Şekil 8.Aşırı boşluk suyu basıncı gelişimi $\Delta p$ : tekrarlı yük sayısı $N=6.25$ 
Açık Deniz Yapıları Kova Temel Sistemi Davranışı Üzerinde Tekrarlı Yük ...

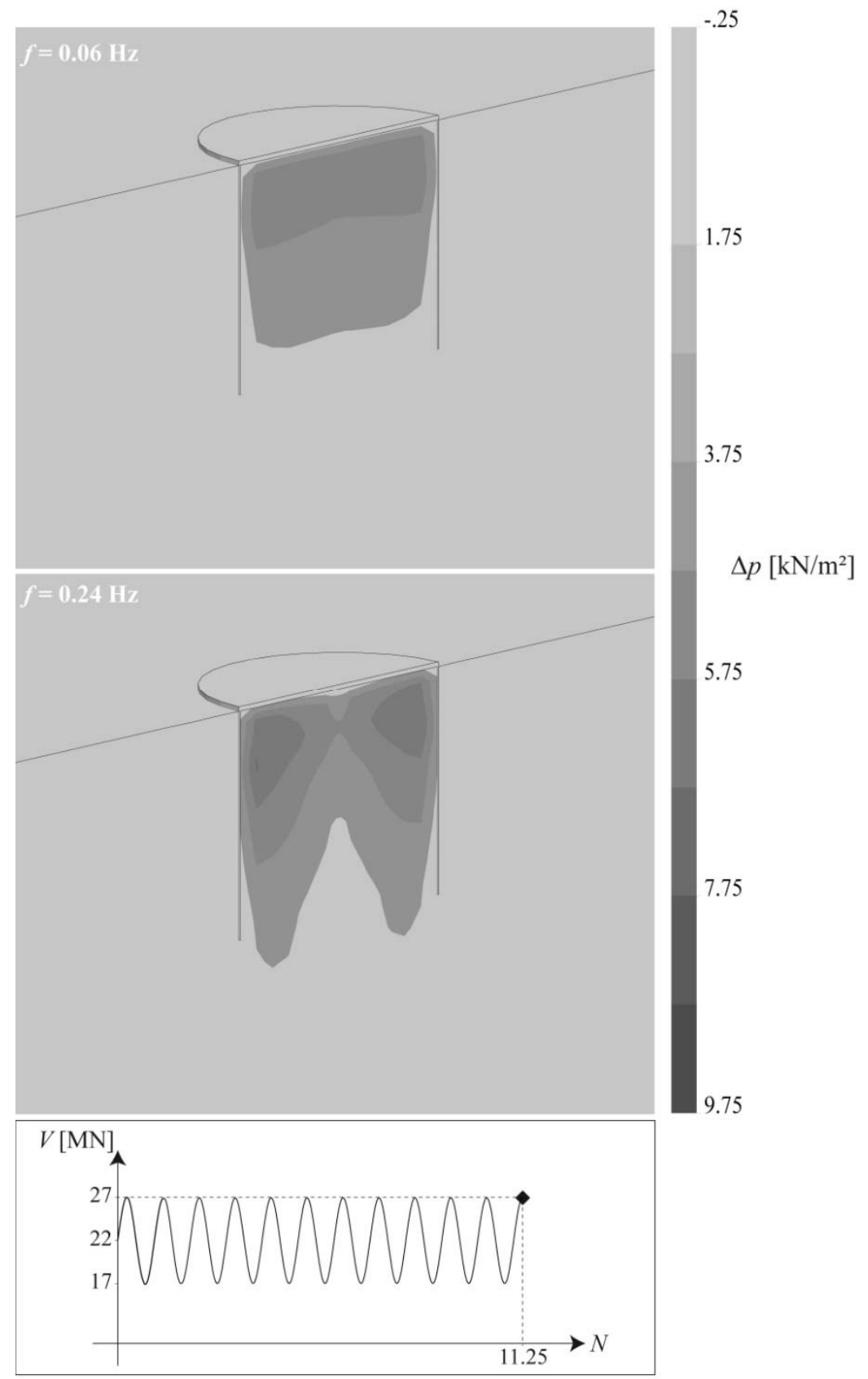

Şekil 9. Aşırı boşluk suyu basıncı gelişimi Ap: tekrarlı yük sayısı $N=11.25$ 
Sonuçlar, homojen suya doygun kumlu zemin koşullarında yükleme hızının aşırı boşluk suyu basıncı gelişimi üzerinde önemli bir etkisi olduğunu ortaya çıkarmıştır. Yükleme frekansı sadece aşırı boşluk suyu basıncı gelişimini büyüklük olarak değil aynı zamanda yayılım olarak da etkilemiştir.

Sayısal analiz sonuçlarında aşırı boşluk suyu basıncı birikiminin zeminin dayanım ve rijitliğinin tamamen kaybına neden olabileceği değerlere ulaşmadığı saptanmıştır. Örneğin aşırı boşluk suyu basıncı birikimin daha yüksek değerde gerçekleştiği hızlı yükleme durumu için $(f=0.24 \mathrm{~Hz})$ ve yük tekrar sayısı $N=2.25$ anında aşırı boşluk suyu basıncının efektif düşey gerilmeye oranını ifade eden $\Delta p /\left(\gamma^{\prime} z\right)$ oranı $0.1 l$ derinliğinde $\% 56$ mertebesinde elde edilmiştir. Başlangıç yük tekrarlarında yüksek değerde elde edilen aşırı boşluk suyu basıncının sönümlenme hızı ilerleyen yük tekrarlarındaki boşluk suyu basıncının gelişme hızından yüksek olduğundan ilerleyen tekrarlarda başlangıç değerlerine göre daha düşük aşırı boşluk suyu basıncı birkimi elde edilmiştir. Bu davranış yük frekansına bağlı bir davranıştır. Birbirini takip eden iki yük arasındaki zaman dilimi azaldıkça sönümlenme hızı düşecektir. Ayrıca zemin hipoplastik malzeme modelince öngörüldüğü üzere ilerleyen tekrarlarda daha düşük boşluk suyu basıncı gelişimi davranışına yük tekrar sayısı arttıkça zemin sıkılığının artması katkı sağlamıştır.

Bu çalışma kapsamında aşırı boşluk suyu basıncı gelişimi $N=11.25$ yük tekrar sayısına kadar incelenmiş ve ilerleyen tekrar sayıları durumu için gelişim numerik hesaplama hatalarının birikimi sebebiyle ele alınmamıştır. Denizel ortamda karşılaşılacak çok daha yüksek tekrar sayılarındaki durumun incelenmesinin ilerleyen çalışmalarda uygun zemin modeli ile gerçekleştirilmesi planlanmaktadır.

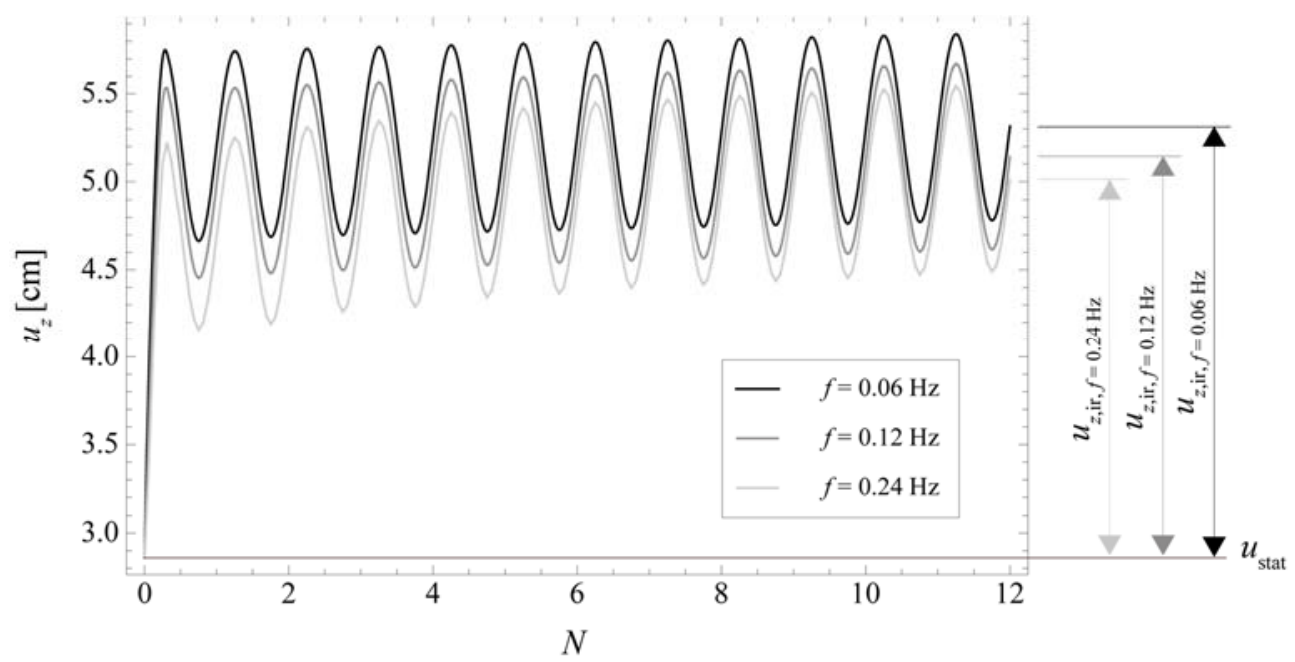

Şekil 10. Yük tekrar sayısl-kova temel üst plakası deplasman ilişkisi: Frekans; $f=0.06 \mathrm{~Hz}$, $0.12 \mathrm{~Hz}, 0.24 \mathrm{~Hz}$ 
Analizler sonucu eksenel statik ve farklı frekanslara sahip $(f=0.06 ; 0.12 ; 0.24 \mathrm{~Hz})$ tekrarlı yükleme koşullarında temel üst plakasında meydana gelen deplasman birikimi $u_{z}$ elde edilmiştir (Şekil 10). Statik ölü yük nedeniyle üst plakada $u_{z \text {,stat }}=2.9 \mathrm{~cm}$ lik bir oturma gerçekleşmiştir. Ardından uygulanan ilk tekrarlı yükleme sonrası deplasman artmış ve devam eden tekrarlarda deplasman birikiminde azalarak artış gözlemlenmiştir. Uygulanan $f=0.06$, $f=0.12, f=0.24 \mathrm{~Hz}$ yük frekansı durumlarında meydana gelen kalıcı deformasyonlar sırasıyla $u_{z, \text { ir }}=2.5 \mathrm{~cm}, 2.3 \mathrm{~cm}, 2.2 \mathrm{~cm}$ olarak elde edilmiştir.

Sonuçlar göstermektedir ki en yüksek kalıcı deformasyon en düşük frekanslı tekrarlı yükleme durumunda gerçekleşmiştir. Tekrarlı yüklemelerde düşük frekansın etkisi farklı laboratuvar deney ve sayısal analiz çalışmaları ile incelenmiştir [38-40]. Söz konusu araştırmalarda, birbirini takip eden aynı yükler arasındaki zaman farkının zemin deformasyonu üzerinde önemli bir etkisi olduğu belirlenmiştir. Düşük frekanslı yükleme durumunda zeminde aşırı boşluk suyu basıncının sönümlenmesi ve suyun drenajı hızlı yüklemeye göre daha etkin bir şekilde meydana gelmektedir. Böylelikle yavaş yükleme durumunda daha yüksek zemin deformasyonu oluşmaktadır.

\section{SONUÇLAR}

Bu çalışmada kova-temelin eksenel tekrarlı yükleme altındaki davranışı üç boyutlu sonlu elemanlar yöntemi ile incelenmiştir. Sonlu elemanlar analizlerinde tekrarlı yük etkisi altında zeminlerin modellenmesine uygun hipoplastik malzeme modeli kullanılmıştır. Suya doygun zemin-yapı etkileşimi ve aşırı boşluk suyu basıncı gelişiminin gerçekçi bir şekilde incelenebilmesi amacıyla zemin iki fazlı üç boyutlu elemanlar ile modellenmiştir. Çalışmada özellikle yük frekansının, başka bir ifade ile tekrarlı yükleme hızının, aşırı boşluk suyu gelişimi ve temel deplasman birikimi üzerindeki etkisine odaklanılmıştır. Bu amaçla analizler üç farklı $f=0.06,0.12$ ve $0.24 \mathrm{~Hz}$ yük frekanslarında gerçekleştirilmiştir.

Analizler sonucu elde edilen bulgular maddeler halinde aşağıda sıralanmıştır:

- Eksenel tekrarlı yükleme nedeniyle temel içindeki zeminde aşırı boşluk suyu basıncı gelişimi gerçekleşmiştir. En yüksek değerde aşırı boşluk suyu basıncı gelişimi başlangıç yük tekrarlarında meydana gelmiştir.

- Maksimum aşırı boşluk suyu basıncı yüksek frekanslı tekrarlı yükleme durumunda gerçekleşmiştir. Yüksek frekanslı yükleme durumunda aynı zamanda aşırı boşluk suyu basıncının gelişimi daha derinlere doğru yayılım göstermiştir. İlk tekrar yükünü takip eden tekrarlarda aşırı boşluk suyu basıncı azalma eğilimi gösterse de lokalize olma özelliğini kısmen korumuş ve düşük frekanslı yüklemeye göre daha derinlerde oluşmaya devam etmiştir.

- Özellikle düşük frekanslı yüklemede ilk yük tekrarını takip eden yük tekrarlarında aşırı boşluk suyu basınç değeri azalmış ve lokalize olma özelliğini yitirme eğilimi göstermiştir.

- Tekrarlı eksenel yükleme altında temelde kalıcı deplasman birikimi meydana gelmiştir. Kalıcı deplasman birikimi her yük tekrarında azalan bir artışla gerçekleşmiştir. 
- Çalışma kapsamında elde edilen sonuçlar göstermektedir ki aynı yük tekrarında en düşük frekansta en yüksek kalıcı deplasman birikimi oluşmaktadır.

- Araştırmada ele alınan yük, temel sistemi ve zemin koşullarında oluşan aşırı boşluk suyu basıncı gelişimi suya doygun zeminin bütünüyle dayanım ve rijitlik kaybına neden olacak nihayi değere ulaşmamıştır.

Günümüz itibarıyla açık deniz yapıları için kova temel sistemi davranışının tahmini ve taşıma kapasitesi ile ilgili henüz pratik bir hesaplama yöntemi bulunmamaktadır. Bu anlamda, çalışmanın ileriki aşamalarında kova temel sisteminin kullanım ömrü boyunca gelişecek deplasman değerlerinin ve birikiminin tahminine yönelik devam eden araştırmalar gerçekleştirilecektir.

\section{Semboller}

E : Elastisite modülü $\left[\mathrm{N} / \mathrm{m}^{2}\right]$

$I_{\mathrm{D}} \quad$ : Rölatif Sikılık

$N \quad$ : Yük tekrar sayısı

$R \quad$ : Hipoplastik malzeme modeli daneler arası birim deformasyonu

$V \quad:$ Eksenel yük [N]

$V_{\text {stat }} \quad$ : Statik eksenel yük [N]

$\tilde{V} \quad$ : Tekrarlı eksenel yük büyüklüğü [N]

$e_{c 0} \quad$ : Kritik boşluk oranı

$e_{d 0} \quad$ : Minimum boşluk oranı

$e_{i 0} \quad$ : Maksimum boşluk oranı

$d \quad$ : Kova temel üst plaka çapı [m]

$f \quad$ : Tekrarlı yük frekansı [Hz]

$h \quad$ : Ortalama deniz taban derinliği [m]

$h_{\mathrm{s}} \quad$ : Hipoplastik malzeme modeli rijitlik parametresi $\left[\mathrm{N} / \mathrm{m}^{2}\right]$

$k_{\mathrm{d}} \quad:$ Permeabilite $[\mathrm{m} / \mathrm{s}]$

$l \quad:$ Kova temel derinliği $[\mathrm{m}]$

$m_{\mathrm{R}} \quad$ : Hipoplastik malzeme modeli rijitlik faktörü

$m_{\mathrm{T}} \quad$ : Hipoplastik malzeme modeli rijitlik faktörü

$n \quad$ : Hipoplastik malzeme modeli: üstel bir parametre

$p \quad$ : Boşluk suyu basıncı $\left[\mathrm{N} / \mathrm{m}^{2}\right]$

$t \quad$ : Zaman [s] 


$$
\begin{aligned}
& t_{0} \quad \text { : Kova temel et kalınlığ }[\mathrm{m}] \\
& u_{x} \quad: x \text {-yönündeki deplasman }[\mathrm{m}] \\
& u_{y} \quad: y \text {-yönündeki deplasman [m] } \\
& u_{z} \quad: z \text {-yönündeki deplasman }[\mathrm{m}] \\
& u_{z, \text { ir }}: z \text {-yönündeki kalıcı deplasman [m] } \\
& u_{z, \text { stat }}: z \text {-yönündeki statik deplasman [m] } \\
& \alpha \quad \text { : Hipoplastik malzeme modeli parametresi } \\
& \beta_{\mathrm{r}} \quad \text { : Hipoplastik malzeme modeli: üstel bir parametre } \\
& \chi \quad \text { : Hipoplastik malzeme modeli: üstel bir parametre } \\
& \delta \quad \text { : Sürtünme aç1s1 }\left[{ }^{\circ}\right] \\
& \Delta p \quad \text { : Aşırı boşluk suyu basıncı }\left[\mathrm{N} / \mathrm{m}^{2}\right] \\
& \left.\gamma^{\prime} \quad \text { : Efektif birim hacim ağırlığ } 1 \mathrm{~N} / \mathrm{m}^{3}\right] \\
& \gamma_{\mathrm{d}, \min }: \text { Minimum kuru birim hacim ağırlığ }\left[\mathrm{N} / \mathrm{m}^{3}\right] \\
& \gamma_{\mathrm{d}, \max }: \text { Maksimum kuru birim hacim ağırlığ }\left[\mathrm{N} / \mathrm{m}^{3}\right] \\
& \left.\gamma_{\mathrm{s}} \quad \text { : Dane birim hacim ağırlığ } 1 \mathrm{~N} / \mathrm{m}^{3}\right] \\
& \left.\varphi_{\mathrm{c}} \quad \text { : Gevşek durum için kritik içsel sürtünme açısı [ }{ }^{\circ}\right] \\
& v \quad \text { : Poisson oranı } \\
& \circ \quad \text { : Jaumann gerilme oranı (2. Dereceden tensör) } \\
& \sigma \quad \text { : Mevcut gerilme durumu (2. Dereceden tensör ) } \\
& \text { L : Tensörel fonksiyon (4. Dereceden tensör ) } \\
& \mathrm{N} \text { : Tensörel fonksiyon (2. Dereceden tensör ) } \\
& \dot{\varepsilon} \quad \text { : Birim deformasyon oranı (2. Dereceden tensör) } \\
& \text { F : Skaler gerilme fonksiyonu } \\
& \text { a : Skaler gerilme fonksiyonu }
\end{aligned}
$$

\section{Teşekkür}

Çalışmalar, Alman Araştırma Cemiyeti'nin (DFG) katkılarıyla TA 1235/2-1 nolu proje kapsamında yürütülmüştür. Desteklerinden dolayı teşekkürlerimizi sunarız. 


\section{Kaynaklar}

[1] Byrne, B.W., Houlsby G.T., Foundation for offshore wind turbines, Phil. Trans. Roy. Soc. London. A 361, 2909-2930, 2003.

[2] Zaaijer, M. B., Comparison of monopile, tripod, suction bucket and gravity base design for a 6 MW turbine, Offshore Wind energy in Mediterranean and Other European Seas (OWEMES conference), Naples, Italy, 2003.

[3] Thieken, K., Achmus, M., Schröder, C., On the behavior of suction buckets in sand under tensile loads, Computers and Geotechnics, 60, 88-100, 2014.

[4] Achmus, M., Schröder, C., Installation und Tragverhalten von Bucketgründungen für Offshorebauwerke, Bautechnik, 91 (9), 597-608, 2014.

[5] Houlsby, G.T., Byrne, B.W., Design procedures for installation of suction caissons in sand. Proceedings of the ICE - Geotechnical Engineering, 158(3), 135 -144, 2005.

[6] Senders, M., Suction caissons in sand as tripod foundations for offshore wind turbines, PhD Thesis, Univ. of Western Australia, Perth, Australian, 2008.

[7] Ibsen, L.B., Thilsted, C.L., Numerical study of piping limits for installation of large diameter buckets in layered sand. In: T. Benz, S. Nordal (Eds.), Proceedings of the seventh European conference on numerical methods in geotechnical engineering, Trondheim, Norway. 921-926, 2010.

[8] Zhang, J.H., Zhang, L.M., Lu, X.B., Centrifuge modelling of suction bucket foundations for platforms under ice-sheet-induced cyclic lateral loadings, Ocean Engineering, 34(8-9), 1069-1079, 2007.

[9] LeBlanc, C., Design of offshore wind turbine support structures, $\mathrm{PhD}$ Thesis, Aalborg Univ., Aalborg, Denmark, 2009.

[10] Kim, D.-J., Choo, Y.W., Kim, J.-H., Kim, S., Kim, D.-S., Investigation of monotonic and cyclic behavior of tripod suction bucket foundations for offshore wind towers using centrifuge modeling, J. Geotech. Geoenviron. Eng., 140(5), 1-10, 2014.

[11] Achmus, M., Thieken, K., Numerical Simulation of the Tensile Resistance of Suction Buckets in Sand, Journal of Ocean and Wind Energy, 1(4), 231-239, 2014.

[12] Villalobos, F.A., Model testing of foundations for offshore wind turbines, $\mathrm{PhD}$ Thesis, University of Oxford, United Kingdom, 2006.

[13] Foglia A., Ibsen, L.B., Andersen, L.V., Roesen, H.R., Physical modelling of bucket foundation under long-term cyclic lateral loading, Proceedings of the Twenty-second International Offshore and Polar Engineering Conference, International Society of Offshore \& Polar Engineers, Rhodes, Greece, 667-673, 2012.

[14] Zhu, B., Byrne, B.W., Houlsby, G.T., Long-term lateral cyclic response of suction caisson foundations in sand, J. Geotech. Geoenviron. Eng., 139(1), 73-83, 2013.

[15] Houlsby, G.T., Ibsen, L.B., Byrne, B.W., Suction Caissons for Wind Turbines. In: Gourvenec, Cassidy (Eds.), Frontiers in Offshore Geotechnics: ISFOG2005, Taylor \& Francis Group, London, 2005. 
[16] Taşan, H.E., Numerische Untersuchungen zum Tragverhalten von Saugrohrgründungen unter zyklisch axialen Druckeinwirkungen, Bautechnik, 92(9), 595-604, 2015.

[17] Martin, G.R., Finn, W.D.L, Seed, H.B., Fundamentals of liquefaction under cyclic loading, Journal of the Geotechnical Engineering Division, 101(5), 423-438, 1975.

[18] Andersen, K.H., Bearing capacity under cyclic loading - offshore, along the coast, and on land. The 21st Bjerrum Lecture presented in Oslo, 23 November 2007, Can. Geotech. J., 46(5), 513-535, 2009.

[19] ANSYS, INC., Programmer's manual for ANSYS, Release 14.0., 2011

[20] Bauer, E., Calibration of a comprehensive hypoplastic model for granular materials, Soils and Foundations, 36(1), 13-26, 1996.

[21] Gudehus, G., A comprehensive constitutive equation for granular materials, Soils and Foundations, 36(1), 1-12, 1996.

[22] Kolymbas, D., A rate-dependent constitutive equation for soils, Mech. Res. Comm., 4 (6), 367-372, 1977.

[23] Wu, W., Hypoplasticity as a mathematical model for the mechanical behavior of granular materials, Publication Series of the Institute of Soil Mechanics and Rock Mechanics, Karlsruhe University, No: 129, Germany, 1992.

[24] Niemunis, A., Herle, I., Hypoplastic model for cohesionless soils with elastic strain range, Mechanics of Cohesion-Fractional Materials, 2(4), 279-299, 1997.

[25] von Wolffersdorff, P.-.A., Hypoplastic Relation for Granular Materials with a Predefined Limit State Surface, Mechanics of Cohesive-Frictional Materials, 1(3), 251271, 1996.

[26] J. Lanier, D. Caillerie, R. Chambonn, G. Viggiani, P. Bésuelle and J. Desrues, A general formulation of hypoplasticity, International Journal for Numerical and Analytical Methods in Geomechanics, 28, 1461-1478, 2004

[27] Kolymbas, D., Eine konstitutive Theorie für Böden und andere körnige Stoffe, Veröffentlichung des Institutes für Bodenmechanik und Felsmechanik der Universität Fridericana in Karlsruhe, Deutschland, 1988.

[28] Herle, I., Hypoplastizität und Granulometrie einfacher Korngerüste, Veröffentlichung des Institutes für Bodenmechanik und Felsmechanik der Universität Fridericana in Karlsruhe, Deutschland, 1997.

[29] Vermeer P. A., Verruijt, A., An accuracy condition for consolidation by finite elements, International Journal for Numerical and Analytical Methods in Geomechanics, 5, 1-14, 1981.

[30] Pastor, M., Li, T., Merodo, J. A. F., Stabilized finite elements for harmonic soil dynamics problems near the undrained-incompressible limit, Soil Dynamics and Earthquake Engineering, 16, 161-171, 1997.

[31] Masud, A., Hughes, T. J. R., A stabilized mixed finite element method for Darcy flow, Computer Methods in Applied Mechanics and Engineering, 191, 4341- 4370, 2002. 
[32] Zienkiewicz, O. C., Qu, S., Taylor, R. L., Nakazawa, S., The patch test for mixed formulations, International Journal for Numerical Methods in Engineering, 23 (10), 1873-1883, 1986.

[33] Babuška, I., The finite element method with lagrangian multipliers, Numerische Mathematik, 20 (3), 179-192, 1973.

[34] Brezzi, F., On the existence, uniqueness and approximation of saddle point problems arising from lagrangian multipliers, RAIRO 8-R2, 129-151, 1974.

[35] Taşan, H. E., Rackwitz F., Savidis, S., Behaviour of cyclic laterally loaded large diameter monopiles in saturated sand. 7th European Conference on Numerical Methods in Geotechnical Engineering, NUMGE, Trondheim, Norway, 889-894, 2010.

[36] Booker, J.R., The Consolidation of a Finite Layer Subject to Surface Loading, International Journal of Soils and Structures, 10(7), 1053-1065, 1974.

[37] Offshore Standard DNV-OSJ101 - Design of Offshore Wind Turbine Structures, Det Norske Veritas January, 2014.

[38] Ghosh, B., Madabhushi, S.P.G., A numerical investigation into effects of single and multiple frequency earthquake motions. Soil Dynamics and Earthquake Engineering, 23(8), 691-704, 2003.

[39] Matesic, L., Vucetic, M., Strain-rate effect on soil secant shear modulus at small cyclic strains, J. Geotech. Geoenviron. Eng., 129(6), 536-549, 2003.

[40] Rascol, E., Cyclic properties of sand: dynamic behaviour for seismic applications, $\mathrm{PhD}$ Thesis, École Polytechnique Fédérale de Lausanne EPFL, Switzerland, 2009. 
